Original Research Article

\title{
Cost-effectiveness of newer anti-emetics in the prevention of chemotherapy induced nausea and vomiting: a pharmaco-economic study analysis
}

\author{
Akshay J. K. ${ }^{1}$, Basavanna P. L. ${ }^{2 *}$
}

${ }^{1}$ Department of Pharmacology, ${ }^{2}$ Department of Clinical Pharmacology, Mysore Medical College and Research Institute, Mysuru, Karnataka, India

Received: 17 March 2018

Revised: 03 April 2018

Accepted: 25 April 2018

*Correspondence to:

Dr. Basavanna P. L.,

Email: drbasavannapl@ gmail.com

Copyright: (C) the author(s), publisher and licensee Medip Academy. This is an openaccess article distributed under the terms of the Creative Commons Attribution NonCommercial License, which permits unrestricted noncommercial use, distribution, and reproduction in any medium, provided the original work is properly cited.

\begin{abstract}
Background: Chemotherapy induced Nausea and Vomiting (CINV) is one the most common adverse effects associated with chemotherapeutic management of carcinoma breast. Preventing CINV becomes a vital part in treatment of these cancer patients for better compliance. The conventional regimen of newer 5-HT3 receptor antagonist and dexamethasone along with newer agents - Aprepitant, a NK-1 receptor antagonist and a recently approved atypical antipsychotic, Olanzapine have shown better control of CINV. These newer agents are effective but also very expensive.

Methods: The study included carcinoma breast patients scheduled for chemotherapy ( $n=55$ in each group) who either received aprepitant or olanzapine or a combination of both as the anti-emetic regimen. Considering CostEffectiveness Analysis (CEA), the cost included was the cost of anti-emetic agents (sponsor's perspective) and outcome measured as control of nausea and vomiting - as Complete Protection (CP), Complete Response to Best (CRB) and Incomplete Response (IR) for acute (0-24 hours) and delayed (24-120 hours) phases. The cost effectiveness(CE) ratio for emesis and CINV free days were calculated.
\end{abstract}

Results: CP was seen better during the acute period than the delayed period. With Aprepitant, delayed CRB and IR was seen with 13 (23.6\%) and 10 (18.2\%) subjects. 16 (29.1\%) showed IR with Olanzapine during the delayed period.

The average number of Emesis and CINV free days were 4.65, 4.51, 4.89 and $3.38,3.96,4.15$ for the three groups respectively. The cost required to achieve 1 emesis and 1 CINV free day per subject in the 3 groups was INR 351.19, INR 27.20, INR 339.54 and INR 483.36, INR 30.94, INR 400.60 respectively.

Conclusions: The newer anti-emetic even though being expensive at cost, pharmacoeconomically provide better outcomes and seem to have better control rates than the conventional regimen.

Keywords: Anti-emetics, Chemotherapy induced nausea and vomiting, Cost effective analysis, Pharmaco-economics

\section{INTRODUCTION}

Chemotherapy Induced Nausea and Vomiting (CINV) is the most common side effect of cancer chemotherapy which is the most discomforting and distressing event for patients and can interfere with their daily activities, reduce their quality of life (QoL) and even interfere with compliance to their treatment of chemotherapy. ${ }^{1-6}$
Chemotherapy induced nausea and vomiting (CINV) can be classified into anticipatory (before chemotherapy) or acute (up to 24 hours, post chemotherapy) and delayed ( 24 to 120 hours i.e. up to 5 days post chemotherapy). ${ }^{7}$ Different chemotherapeutic agents have different emetogenic potential based on the dose and route of administration..$^{8-10}$ Increased number of nausea and emetic episodes prevent patients from adhering to treatment and 
thus, adequate control of CINV is very essential for effective delivery of chemotherapeutic agents. Patients with CINV may require additional outpatient or inpatient emergency interventional medical care, adding to the cost of cancer therapy and loss of effective working days which poses and an economical burden on these patients. ${ }^{6,11,12}$

Successful control of CINV in the initial cycle of the chemotherapy has shown to provide a decreased incidence of CINV in the further subsequent cycles. ${ }^{5,13,14}$ In addition to this, patients experiencing no emesis in the acute phase are less likely to experience emesis in the delayed phase. ${ }^{15}$ Thus, preventing CINV on the first day of the first cycle of chemotherapy becomes very important.

Various anti-emetic agents have been approved and used efficiently for the control and prevention of CINV over the years. The conventional agents include, (i) $5-\mathrm{HT}_{3}$ receptor antagonist like ondansetron, granisetron and dolasetron (ii) A $\mathrm{D}_{2}$ receptor blocker - Metoclopramide and (iii) anticholinergic agents. ${ }^{16-22}$ But with the use of these agents, about $20-30 \%$ of patients still experienced acute CINV and more than $50 \%$ had control over delayed CINV. ${ }^{23,24}$ But, newer agents like:

- Newer 5-HT3 receptor antagonist like Palonosetron

- Neurokinin-1 (NK1) receptor antagonist. ${ }^{25}$

- Dexamethasone and

- a recently approved atypical antipsychotic Olanzapine. ${ }^{26-28}$

have shown better control of CINV when administered against moderately and highly emetogenic chemotherapeutic agents.

Breast cancer patients usually receive a combination of anthracycline (doxorubicin or epirubicin) and cyclophosphamide with or without 5-flurouracil. ${ }^{29,30}$ Anthracyclines and cyclophosphamide individually are classified as moderately emetogenic chemotherapy (MEC) agents. But, when administered as a combination, their emetogenicity increases to highly emetogenic chemotherapy (HEC). ${ }^{31}$ Multinational Association of Supportive Care in Cancer/European Society of Medical Oncology (MASCC/ESMO) in 2010 have laid down the newer guidelines and regimen for the prevention of CINV due to anthracycline and cyclophosphamide combination for carcinoma breast. ${ }^{32}$ The newer regimen used include T. Aprepitant $125 \mathrm{mg}$ PO with Inj. Palonosetron $0.25 \mathrm{mg}$ IV and Inj. Dexamethasone $8 \mathrm{mg} / 16 \mathrm{mg}$ on Day 1 of chemotherapy followed by T. Aprepitant $80 \mathrm{mg}$ PO on Day 2 and 3. Recently, T. Olanzapine $10 \mathrm{mg}$ PO has also been shown to be effective than the conventional anti-emetic regimens for prevention of $\mathrm{CINV} .^{33,34}$

But, these newer agents are economically highly priced and also have a larger adverse effect profile. And even with the guidelines in practice for quite some years now, the hospitals, especially the government hospitals still stick to the conventional and older anti-emetic agents as they are easily available and economically cost less. The clinicians are forced to prescribe and stick to the older agents even though the newer have proven to show better efficacy and safety.

Pharmacoeconomics is a part of pharmacology which compares cost with the clinical outcome for a wholesome better economical assessment. The types of pharmacoeconomic study tools available are: ${ }^{35}$

- $\quad$ Cost Minimisation Analysis (CMA)

- Cost Effectiveness Analysis (CEA)

- $\quad$ Cost Utility Analysis (CUA)

- Cost Benefit Analysis (CBA)

This study uses Cost Effectiveness Analysis techniques which aims at determining and comparing the total cost (cost to treatment of anti-emetic agents used as prophylaxis for CINV) with the outcome (control of nausea and vomiting post chemotherapy) for these newer anti-emetic agents.

\section{METHODS}

The study population included all patients diagnosed as carcinoma breast scheduled for first cycle chemotherapy with doxorubicin and cyclophosphamide, either treated prophylactically with aprepitant, palonosetron and dexamethasone or olanzapine, palonosetron and dexamethasone or combination of aprepitant, olanzapine along with palonosetron and dexamethasone. Individuals was each group were assessed for control of nausea and vomiting over 5 days period, after initiation of chemotherapy with MASCC anti-emetic tool and visual analogue scale for nausea. The study population was the part of the study subjects, who were a part of the clinical trial comparing the efficacy and safety of aprepitant and olanzapine in prevention of CINV in carcinoma breast patients. The patients were asked to mark the extent of nausea affecting them on the visual analogue scale and make a note of emetic episodes on the provided predesigned form by the investigator, everyday starting from the day of chemotherapy (Day 1) up to Day 5. The filled forms were used in the study with the permission of the principle investigator of the trial for pharmacoeconomic and cost-effective analysis of the anti-emetic agents.

Control of nausea and vomiting was recorded for acute period (0-24 hours post chemotherapy) and delayed period (24-120 hours, Day 2- Day 5 post chemotherapy). The total cost for the CEA analysis included the total cost of the antiemetic agents provided by the sponsor (investigator of the trail), rescue treatment and any other cost required to manage the side effects related to the use of the drugs used in the trial. The other direct and indirect costs were not included as the analysis was performed from the sponsor's perspective. The outcome for the analysis was assessed separately for acute and delayed periods with the help of three variables: 
1. Complete Protection (CP) - no episode of emesis or use of rescue medication and nausea $\leq 2$ on the visual analogue scale

2. Complete Response at Best (CRB) - no episode of emesis or use of rescue medication and nausea $>2$ on the visual analogue scale

3. Incomplete Response (IR) - history of emesis and/or use of rescue medication and any nausea $0-10$ on the visual analogue scale

The cost to effect ratio was calculated for each of the three groups over acute and delayed phases for complete protection $(\mathrm{CP})$, complete response at best $(\mathrm{CRB})$ and incomplete response (IR). Also, the cost effectiveness (CE) ratio, to achieve one emesis free day and one CINV free day for each of the agents/combinations was calculated and compared.

\section{RESULTS}

A total of 165 patients were analysed with 55 in each of the APD (aprepitant, palonosetron, dexamethasone) regimen group, OPD (olanzapine, palonosetron, dexamethasone) regimen group and OAPD (olanzapine + aprepitant, palonosetron, dexamethasone) regimen group.

Complete protection (CP) was achieved in 41 (74\%), 46 $(84 \%), 49(89 \%)$ and $32(58 \%), 37(67 \%), 41(74 \%)$ respectively during the acute and delayed periods in the three groups separately (Figure 1).

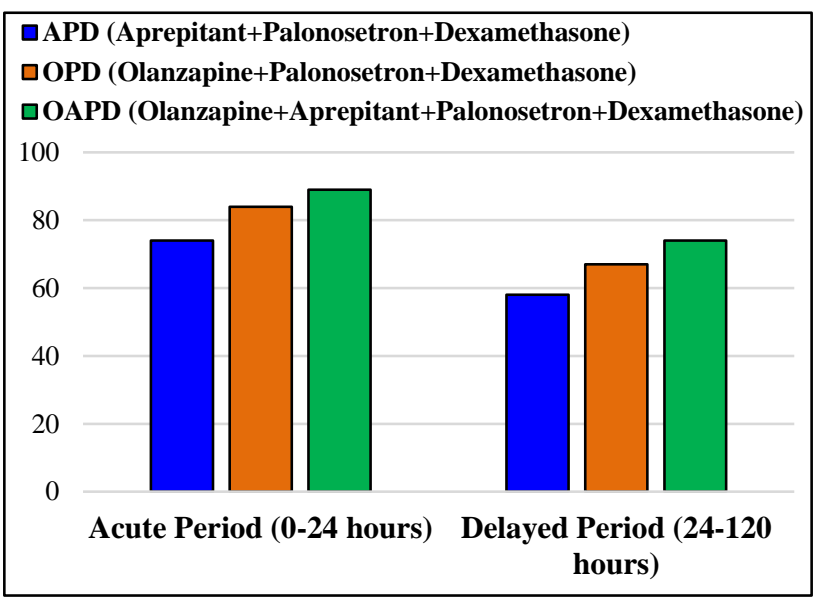

Figure 1: Complete Protection (CP) towards CINV.

Compete response at best (CRB) was seen in 9, 5, 5 and $13,2,12$ patients respectively during the acute and delayed phases (Figure 2).

Incomplete response (IR) was seen in $5(9 \%), 4(7 \%), 1$ $(2 \%)$ in the acute period which increased to $10(18 \%), 16$ (29\%), 2 (3.5\%) during the delayed period respectively for the three groups (Figure 3).

The total cost for each of the regimens per cycle of chemotherapy are as depicted in Table 1.

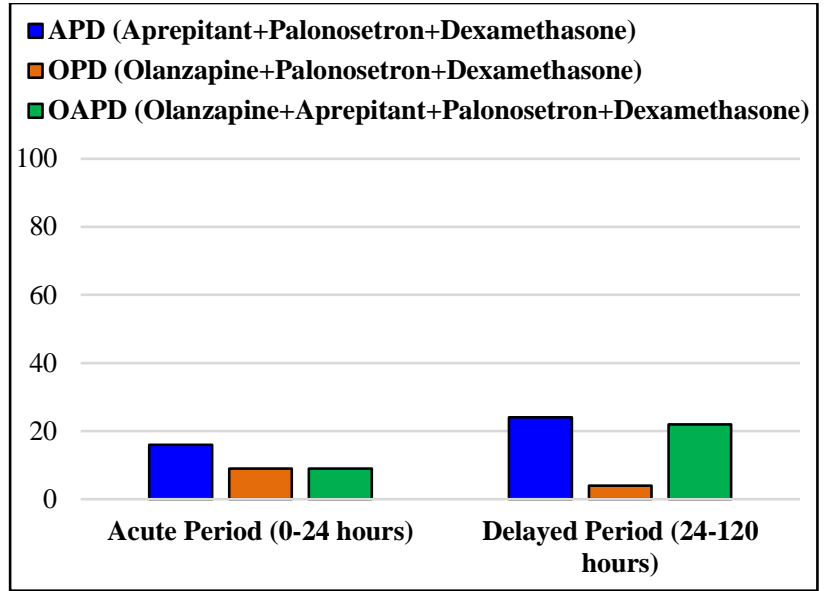

Figure 2: Complete Response at Best (CRB) towards CINV.

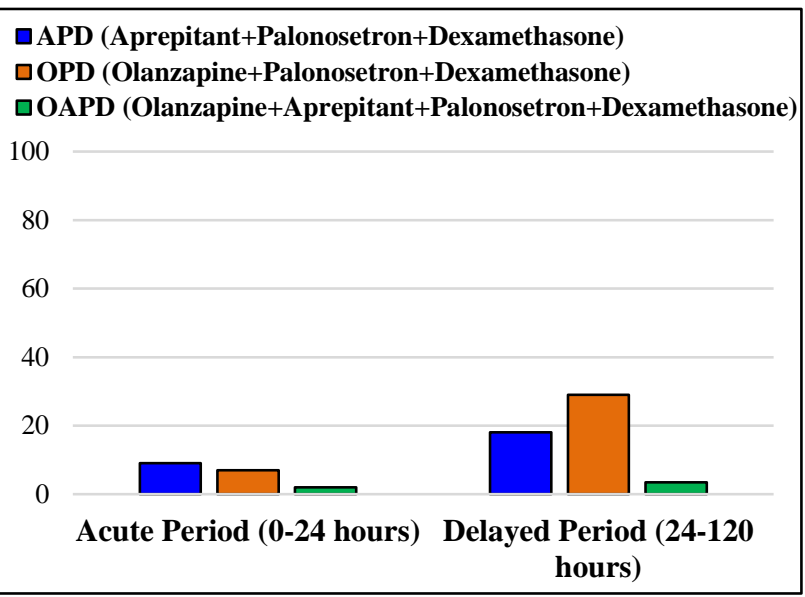

Figure 3: Incomplete Response (IR) towards CINV.

Table 1: Cost of anti-emetic treatment regimen per cycle of chemotherapy.

\begin{tabular}{|ll|}
\hline $\begin{array}{l}\text { Anti-Emetic treatment } \\
\text { regimen }\end{array}$ & $\begin{array}{l}\text { Total cost of the regimen } \\
\text { per cycle of chemotherapy }\end{array}$ \\
\hline $\begin{array}{l}\text { APD (Aprepitant }+ \\
\text { Palonosetron }+ \\
\text { Dexamethasone) }\end{array}$ & 1634.65 INR \\
\hline $\begin{array}{l}\text { OPD (Olanzapine }+ \\
\text { Palonosetron }+ \\
\text { Dexamethasone) }\end{array}$ & 122.65 INR \\
\hline $\begin{array}{l}\text { OAPD Combination } \\
\text { regimen }\end{array}$ & 1670.65 INR \\
\hline
\end{tabular}

The average number of emesis free days were 4.6, 4.51. 4.89 respectively and the average number of CINV free days were estimated to be $3.38,3.96,4.15$ respectively for the three regimens.

The control to control ratio i.e. the Cost Effectiveness (CE) ratio to achieve one emesis free day and one CINV free day was calculated (Table 2). 
Table 2: Cost Effectiveness (CE) ratio of the three groups.

\begin{tabular}{|lll|}
\hline $\begin{array}{l}\text { Cost required to } \\
\text { achieve }\end{array}$ & $\begin{array}{l}\text { ONE Emesis } \\
\text { free day }\end{array}$ & $\begin{array}{l}\text { ONE CINV } \\
\text { free day }\end{array}$ \\
\hline APD Regimen & 351.19INR/Day & 483.36INR/Day \\
\hline OPD Regimen & 27.20INR/Day & 30.94INR/Day \\
\hline OAPD Regimen & 339.54INR/Day & 400.60INR/Day \\
\hline
\end{tabular}

\section{DISCUSSION}

The combination therapy of doxorubicin and cyclophosphamide is highly emetogenic and cause very frequent chemotherapy induced nausea and vomiting (CINV). CINV is due to the action of the receptors like 5$\mathrm{HT}_{3}, \mathrm{D}_{2}$, cholinergic and NK-1 in the CTZ (chemoreceptor triggering zone). This mechanism has been established for delayed phase nausea and vomiting too. The newer antiemetic agents used in the study target these receptors both peripherally and centrally (CTZ), block the actions of these receptors and prevent nausea and vomiting.

This study shows that the cost of using aprepitant, a selective neurokinin-1 antagonist, is high and pricy, the overall clinical control of nausea and vomiting is definitely better and the cost to attain one emesis free day and CINV free day during the course of chemotherapy is 351.19INR and 483.36INR per cycle which is acceptable and so can be used more frequently than the older, conventional agents as aprepitant is more efficacious and safe when used to prevent CINV. Management of cancer, chemo-radiation therapy is provided free of cost to unaffordable people at the government hospitals, but these hospitals still use the older agents. This study shows that the government can incorporate and replace the older agents with these newer agents which seem to be more effective clinically and slightly beneficial economically.

The study also highlights the economical as well as the pharmacological effectiveness of olanzapine, a newly approved agent for CINV. The cost effectiveness ratio with olanzapine to attain an emesis and CINV free day is just 27.20INR and 30.94, which is very economical and acceptable for use in a population like India, where not all can afford a slightly highly priced drug like aprepitant. So, olanzapine can be used in such cases to counteract the emetogenic effects of the chemotherapy. Olanzapine, has proven to be as efficacious as aprepitant in the control and prevention of CINV, safe, well tolerated and definitely more economical as seen in the study.

Nausea is a major problem during the course of chemotherapy and olanzapine seems to be better at controlling nausea than aprepitant and aprepitant better at controlling delayed emetic episodes, so a combination if olanzapine and aprepitant was used to study its effectiveness in preventing CINV. The study clearly shows that the clinically there is better control with the combination therapy (OAPD) and also has a better pharmaco-economical outcome than the APD regimen, as seen by the CE ratios - 351.19INR as compared to 339.54INR to attain an emesis free day respectively as well as $483.36 \mathrm{INR}$ as to $400.60 \mathrm{INR}$ for the two groups respectively.

There are no or very few documented data related to the pharmacoeconomic analysis of the anti-emetic agents for prevention of chemotherapy induced nausea and vomiting (CINV) in India, and definitely very limited data on the use of newer agents like aprepitant and olanzapine. Only a few studies are available from the UK and USA where the costeffective analysis of aprepitant based regimen for CINV in done. Our study results are similar to the studies, which emphasises the need for use of the newer agents. ${ }^{3637}$

One major limitation of this study is that these newer agents have not been compared to the conventional, older agent therapies. So further, extension and comparison of the newer agents with the more commonly, frequently used conventional agents might provide a better and stronger pharmacoeconomic analysis results, which can validate and emphasise the need for the use of these newer agents for the prevention of CINV in cancer chemotherapy and radiotherapy patients.

\section{CONCLUSION}

From this study, we can conclude that even though the conventional agents have been used for decade and are easily, economically available, steps need to be taken to incorporate these highly pharmacoeconomically effective drugs in the government and corporate hospital for better outcome of the patients towards control of nausea and vomiting related to cancer chemotherapy (CINV).

\section{ACKNOWLEDGEMENTS}

Authors would like to thank Dr. Mukesh S, the nursing staff and the entire Department of Oncology, KR Hospital, Mysore Medical College and Research Institute, Mysuru, Karnataka in helping and immense co-operation in conducting this study. Authors also acknowledged Dr. Hemanth Kumar KH, Dr. Scandashree K who guided them throughout the course of the study and pushed them to perform a pharmacoeconomic study. Finally, Dr Mahendra, ISPOR India Chapter and Dr Manjunath, Deparmtent of Pharmacology, PIMS, Pondicherry whose guidance and knowledge was very essential for designing this study.

\section{Funding: No funding sources \\ Conflict of interest: None declared \\ Ethical approval: The study was approved by the Institutional Ethics Committee}

\section{REFERENCES}

1. Piko B, Bassam A. Treatment of tumor therapyinduced nausea and vomiting. Magy Onkol. 2009;53(1):39-45. 
2. Kris MG. Why do we need another antiemetic? Just ask. J Clin Oncol. 2003;21(22):4077-80.

3. Ballatori E, Roila F, Ruggeri B, Betti M, Sarti S, Soru $\mathrm{G}$, et al. The impact of chemotherapy-induced nausea and vomiting on health-related quality of life. Supportive Care in Cancer. 2007 Feb 1;15(2):179-85.

4. Glaus A, Knipping C, Morant R, Böhme C, Lebert B, Beldermann F, et al. Chemotherapy-induced nausea and vomiting in routine practice: a European perspective. Supportive Care in Cancer. 2004 Oct 1;12(10):708-15.

5. Cohen L, de Moor CA, Eisenberg P, Ming EE, Hu H. Chemotherapy-induced nausea and vomiting: incidence and impact on patient quality of life at community oncology settings. Support Care Cancer. 2007;15(5):497-503.

6. Burke TA, Wisniewski T, Ernst FR. Resource utilization and costs associated with chemotherapyinduced nausea and vomiting (CINV) following highly or moderately emetogenic chemotherapy administered in the US outpatient hospital setting. Support Care Cancer. 2011;19(1):131-40.

7. Grunberg SM, Hesketh PJ. Control of chemotherapy induced emesis. N Engl J Med. 1993;329:1790-6.

8. Strum SB, McDermed JE, Pileggi J, Riech LP, Whitaker H. Intravenous metoclopramide: Prevention of chemotherapy-induced nausea and vomiting. A preliminary evaluation. Cancer. 1984 Mar 15;53(6):1432-9.

9. Olver IN, Simon RM, Aisner J. Antiemetic studies: a methodological discussion. Cancer Treat Rep. 1986;70:555-63.

10. Jordan NS, Schauer PK, Schauer A, Nightingale C, Golub G, Martin RS, et al. The effect of administration rate on cisplatin-induced emesis. J of Cli Oncolo. 1985 Apr;3(4):559-61.

11. Ihbe-Heffinger A, Ehlken B, Bernard R, Berger K, Peschel C, Eichler HG, et al. The impact of delayed chemotherapy-induced nausea and vomiting on patients, health resource utilization and costs in German cancer centers. Annals of oncology. 2004 Mar 1;15(3):526-36.

12. Tina Shih YC, Xu Y, Elting LS. Costs of uncontrolled chemotherapy-induced nausea and vomiting among working-age cancer patients receiving highly or moderately emetogenic chemotherapy. Cancer. 2007;110(3):678-85.

13. Morrow GR, Roscoe JA, Hickok JT, Stern RM, Pierce HI, King DB, et al. Initial control of chemotherapyinduced nausea and vomiting in patient quality of life. Oncology-Huntington. 1998 Mar 1;12(4):32-7.

14. Hesketh PJ. Chemotherapy-induced nausea and vomiting. N Engl J Med. 2008;358(23):2482-94.

15. Warr DG, Grunberg SM, Gralla RJ, Hesketh PJ, Roila F, De Wit R, et al. The oral NK1 antagonist aprepitant for the prevention of acute and delayed chemotherapyinduced nausea and vomiting: pooled data from 2 randomised, double-blind, placebo controlled trials. Euro J of Cance. 2005 Jun 1;41(9):1278-85
16. Marty M. Ondansetron in the prophylaxis of acute cisplatin-induced nausea and vomiting. Eur J of Can \& Clin Oncolo. 1989;25:S41-5.

17. Marty M, Pouillart P, Scholl S, Droz JP, Azab M, Brion $\mathrm{N}$, et al. Comparison of the 5hydroxytryptamine3 (serotonin) antagonist ondansetron (GR 38032F) with high-dose metoclopramide in the control of cisplatin-induced emesis. New Engl J of Medic. 1990 Mar 22;322(12):816-21.

18. Hesketh PJ, Harvey WH, Harker WG, Beck TM, Ryan $\mathrm{T}$, Bricker LJ, et al. A randomized, double-blind comparison of intravenous ondansetron alone and in combination with intravenous dexamethasone in the prevention of high-dose cisplatin-induced emesis. J of Cli Oncolo. 1994 Mar;12(3):596-600.

19. Kris MG, Pendergrass KB, Navari RM, Grote TH, Nelson AM, Thomas V, et al. Prevention of acute emesis in cancer patients following high-dose cisplatin with the combination of oral dolasetron and dexamethasone. J of Cli Oncolo. 1997 May;15(5):2135-8.

20. De Mulder PH, Seynaeve C, Vermorken JB, van Liessum PA, Mols-Jevdevic S, Allman EL, et al. Ondansetron compared with high-dose metoclopramide in prophylaxis of acute and delayed cisplatin-induced nausea and vomiting: a multicenter, randomized, double-blind, crossover study. Annals of internal medicine. 1990 Dec 1;113(11):834-40.

21. Hainsworth J, Harvey W, Pendergrass K, Kasimis B, Oblon D, Monaghan G, et al. A single-blind comparison of intravenous ondansetron, a selective serotonin antagonist, with intravenous metoclopramide in the prevention of nausea and vomiting associated with high-dose cisplatin chemotherapy. J of Cli Oncolo. 1991 May;9(5):721-8.

22. Gregory RE, Ettinger DS. 5HT-3 receptor antagonists for the prevention of chemotherapy-induced nausea and vomiting: a comparison of their pharmacology and clinical efficacy. Drugs. 1998;55:173-89.

23. Latreille J, Pater J, Johnston D, Laberge F, Stewart D, Rusthoven J, et al. Use of dexamethasone and granisetron in the control of delayed emesis for patients who receive highly emetogenic chemotherapy. National Cancer Institute of Canada Clinical Trials Group. J of Cli Oncolo. 1998 Mar;16(3):1174-8.

24. Goedhals L, Heron JF, Kleisbauer JP, Pagani O, Sessa C. Control of delayed nausea and vomiting with granisetron plus dexamethasone or dexamethasone alone in patients receiving highly emetogenic chemotherapy: a double-blind, placebo-controlled, comparative study. Annals of Oncology. 1998 Jun;9(6):661-6.

25. Tattersall FD, Rycroft W, Hargreaves RJ, Hill RG. The tachykinin NK1 receptor antagonist CP-99,994 attenuates cisplatin induced emesis in the ferret. Eur $\mathbf{J}$ of Pharmaco. 1993 Nov 30;250(1):R5-6.

26. Hale AS. Olanzapine. $\mathrm{Br} \mathrm{J}$ Hosp Med. 1997;58(9):442-5. 
27. Passik SD, Lundberg J, Kirsh KJ, Theobald D, Donaghy K, Holtsclaw E, et al . A pilot exploration of the antiemetic activity of olanzapine for the relief of nausea in patients with advanced cancer and pain. $\mathrm{J}$ Pain Symptom Manage. 2002;23(6):526-32.

28. Navaro RM, Einhorn LH, Loehrer PJ Sr, Passik SD, Vinson J, McClean J, et al. A phase II trial of olanzapine, dexamethasone and palonosetron for the prevention of chemotherapy-induced nausea and vomiting. Support Care Cancer. 2007;15(11):1285-91.

29. Early Breast Cancer Trialists' Collaborative Group. Comparisons between different polychemotherapy regimens for early breast cancer: meta-analyses of long-term outcome among 100000 women in 123 randomised trials. The Lancet. 2012 Feb 4;379(9814):432-44.

30. National Institute for Health and Clinical Excellence (NICE). Early and locally advanced breast cancer: diagnosis and treatment. Full guideline (CG80); Feb 2009 [updated May 30, 2012]. Available at: http://www.nice.org.uk/CG80FullGuideline.

Accessed Jun 2012.

31. Grunberg SM, Osoba D, Hesketh PJ, Gralla RJ, Borjeson S, Rapoport BL, et al. Evaluation of new antiemetic agents and definition of antineoplastic agent emetogenicity- an update. Supportive care in cancer. 2005 Feb 1;13(2):80-4.

32. Roila F, Herrstedt J, Aapro M, Gralla RJ, Einhorn LH, Ballatori E, et al. Guideline update for MASCC and ESMO in the prevention of chemotherapy-and radiotherapy-induced nausea and vomiting: results of the Perugia consensus conference. Annals of Oncology. 2010 May 1;21(5):v232-43.
33. Warr DG, Hesketh PJ, Gralla RJ, Muss HB, Herrstedt J, Eisenberg PD, et al. Efficacy and tolerability of aprepitant for the prevention of chemotherapy-induced nausea and vomiting in patients with breast cancer after moderately emetogenic chemotherapy. J of Cli Oncolo. 2005 Apr 20;23(12):2822-30.

34. Herrstedt J, Muss HB, Warr DG, Hesketh PJ, Eisenberg PD, Raftopoulos H, et al. Efficacy and tolerability of aprepitant for the prevention of chemotherapy-induced nausea and emesis over multiple cycles of moderately emetogenic chemotherapy. Cancer. 2005 Oct 1;104(7):1548-55.

35. Gupta SK. Proposed Pharmacoeconomics guidelines for India (PEG-1) Second International conference of pharmacoeconomics and outcomes research. IPSOR India. 2013 Sep 30;79:100.

36. Humphreys S, Pellissier J, Jones A. Cost-effectiveness of an aprepitant regimen for prevention of chemotherapy-induced nausea and vomiting in patients with breast cancer in the UK. Cancer Management and Research. 2013;5:215.

37. Moore S, Tumeh J, Wojtanowski S, Flowers C. CostEffectiveness of Aprepitant for the Prevention of Chemotherapy-Induced Nausea and Vomiting Associated with Highly Emetogenic Chemotherapy. Value in Health. 2007 Jan 1;10(1):23-31.

Cite this article as: Akshay JK, Basavanna PL. Cost-effectiveness of newer anti-emetics in the prevention of chemotherapy induced nausea and vomiting: a pharmaco-economic study analysis. Int J Basic Clin Pharmacol 2018;7:1141-6. 